\title{
Histamine and Stress Ulcer: New Components in Organizing a Sequential Trial on Cimetidine Prophylaxis in Seriously Ill Patients and Definition of a Special Group at Risk (Severe Polytrauma)*
}

\author{
W. Lorenz, M. Fischer, H. Rohde, H. Troidl, H.J. Reimann and Ch. Ohmann \\ Divisions of Experimental and General Surgery, Department of Operative Medicine I, University of Marburg (Lahn)
}

\author{
Histamin und Stressulcus: Neue Strukturen \\ in der Darstellung einer Sequentialstudie \\ iiber Cimetidinprophylaxe bei Schwerkranken \\ und Definition einer speziellen Risikogruppe
}

Zusammenfassung. Bei Patienten der chirurgischen Wach- und Intensivstation wurde eine kontrollierte klinische Studie über den Wert von Cimetidin zur Streßulcusprophylaxe durchgeführt. Die übliche Organisation und Darstellung einer kontrollierten Studie mußte wegen erheblicher theoretischer, ethischer und praktischer Schwierigkeiten bei Planung und Durchführung geändert werden:

(1) Zuerst wurde die Untersuchung bei Patienten der Wach- und Intensivstation als randomisierte Doppelblindstudie mit fixem Stichprobenumfang geplant. Ausgeführt wurde eine einfach-blinde Sequentialstudie ausschließlich bei Patienten mit schwerem Polytrauma. Kurz vor Erreichen der vorgegebenen Signifikanzgrenzen wurde sie aus ethischen Gründen abgebrochen und nach Beratung mit einem externen Gutachter mit Hilfe des exakten Testes nach Fisher analysiert $(p<0,025)$.

(2) Die notwendigen Informationen über die Studie konnten nicht in einem einzigen Bericht zusammengepreßt werden. Als einer der Teile enthält diese Mitteilung Plan, Klinisches Material, Methoden und Statistik der Studie. Abschnitte über ,Theoretische und ethische Aspekte“ und über „Historische Entwicklung der Studie" wurden eingefügt. Zahlreiche Entscheidungen wurden bereits in Material und Methodik erläutert, um die enorme Komplexität des Entscheidungsprozesses bei klinischen Studien im Gegensatz zu der bei Tierexperimenten hervorzuheben.

\footnotetext{
* Supported by a grant from Deutsche Forschungsgemeinschaft (SFB 122, D5)

Offprint requests to: Prof. Dr. W. Lorenz (address see page 665)
}

(3) Um Schlüsse von der Stichprobe auf die Zielpopulation zu erleichtern und Risikogruppen für Streßulkusentstehung zu definieren, wurden alle 6,634 $\mathrm{Pa}$ tienten der Klinik während der Dauer der Studie prospektiv auf klinisch-manifeste Streßläsionen untersucht. Als eines der wichtigsten Merkmale wurde weiterhin die Letalitätsrate für die Gesamtgruppe und für Untergruppen der Traumapatienten in unserer Klinik ermittelt.

Streßulcera traten nur bei Patienten der Wachund Intensivstation auf, vor allem bei Patienten mit schwerem Polytrauma und postoperativen Komplikationen. Cimetidin verhütete sie äußerst wirksam beim schwer Polytraumatisierten. Es ist aber unnötig, das Arzneimittel über die Wach- und Intensivstation auszustreuen wie aus einem Füllhorn des Glücks.

Schlïsselwörter: Streßulcus - Ärztliche Ethik - Sequentialstudie - Cimetidin - Schweres Polytrauma

Summary. In patients in a surgical intensive care unit a controlled clinical trial was performed concerned with the pathophysiological functions of histamine in stress ulcer disease and with the influence of cimetidine prophylaxis on this complication. The commonly used organization of a controlled clinical trial was enforced to be changed by considerable theoretical, ethical and practical difficulties in designing and conducting the study:

(1) Initially the trial was planned as randomized double-blind using a fixed sample size of patients obtained from the intensive care unit. It was executed as a sequential single-blind study only in patients with severe polytrauma. For ethical reasons it was stopped before the bounderies were reached and was analysed according to the advice of an external referee using Fisher's exact test $(\mathrm{p}<0.025)$. 
(2) The necessary informations about the trial could not be compressed to one single report. As one of several parts this article mainly deals with Design, Clinical materials, Methods and Statistics of the whole investigation. Distinctive sections on Theoretical and Ethical issues and on Historical development of the study were included. Numerous decisions were explained already in Materials and Methods to emphasize the enormous complexity of the decision process in clinical trials in contrast to that in most of the animal experiments.

(3) In order to facilitate conclusions from our sample to the target population and to define subgroups of patients with a high risk for stress ulceration all 6,634 patients hospitalized in the Surgery Clinic during the time of the study were prospectively investigated for clinically manifest stress ulceration. Furthermore as one of the most important attributes the lethality rate was calculated for the whole group and various subgroups of trauma patients in our hospital.

As a surprising and remarkable result of the study clinically manifest stress ulcers occurred exclusively in our patients in the intensive care unit and among them mainly in those with severy polytrauma and postoperative complications. Cimetidine was highly effective in preventing stress ulceration in severe polytrauma patients. But it seems absolutely unnecessary to distribute this drug in all patients of a surgical intensive care unit like from a cornucopia of happiness.

Key words: Stress ulceration - Medical ethics - Sequential trial - Cimetidine - Severe polytrauma

The therapeutic benefit of the $\mathrm{H}_{2}$-receptor antagonist cimetidine in chronic duodenal ulcer disease has been established through more than numerous controlled clinical trials $[15,18,33,46,71]$. In the prophylaxis and treatment of acute gastroduodenal lesions, however, the advantages of cimetidine have only been suggested by the results of animal experiments [14, $86,100]$, clinical case reports $[6,24,75,94]$, retrospective trials and prospective trials using either historical controls $[13,52,82,107]$ or patients from highly selected groups $[25,26,30,42,76,112]$. Since histamine $\mathrm{H}_{2}$-receptors in acid secretion [9] and microcirculation [41] and histamine release from intra- and extragastric cellular stores $[64,65,105,106]$ are likely to play an important role in the pathogenesis of acute as well as chronic gastroduodenal ulceration it could be expected that therapy using $\mathrm{H}_{2}$-receptor antagonism could offer clinical advantages to patients likely to or developing stress ulcerations.
To test this hypothesis in the clinical setting a controlled trial concerned with the pathophysiological functions of histamine in stress ulcer disease and with the influence of cimetidine prophylaxis on this complications was conceived and conducted. The planning of the study started with the large group of seriously-ill patients in a surgical intensive care unit. Its execution ended up in only the subgroup of patients with severe polytrauma.

From this statement it becomes clear that during the time of investigation we were confronted with so many surprising events and findings that the necessary informations about the trial could not be compressed to one single original report. As one of probably four communications this article especially comprises three aims: (1) Design, Clinical materials and Methods of the trial were described as carefully as possible. (2) New components in organizing performance and presentation of a clinical trial had to be introduced. These include mainly the distinctive sections on Theoretical and Ethical issues and on Historical development of the study. However, it was also necessary to explain the numerous decisions to be made in planning and conducting the study immediately in the section of Materials and Methods and not - as usually demanded - in Discussion. Such deviations from the common organization of a scientific paper were necessary to emphasize the complexity of the decision process in clinical trials. (3) Subgroups of patients with a high risk for stress ulceration were defined especially those with severe polytrauma. Only this group of critically ill patients ended up in the trial on cimetidine prophylaxis. To acchieve the third aim all 6,634 patients hospitalized in the Surgery Clinic during the time of the trial were prospectively investigated for clinically manifest stress u1ceration.

\section{Materials and Methods}

\section{Theoretical and Ethical Issues}

In conceiving the controlled clinical trial on the effects of therapy with cimetidine on the development and outcome of acute gastroduodenal lesions we met considerable difficulties:

(1) In patients of a surgical intensive care unit many pathological states and stressful conditions could be identified which probably were associated with a high risk of acute gastrointestinal ulceration (Table 1). Unfortunately this argument could be validated only by findings from animal experiments, numerous, but retrospective and uncontrolled surveys and a few prospective trials without control groups or without reliable determination of a risk rate. Just to convince ourselves and to form a theoretical data base for our designing the most reliable experimental and clinical studies to our knowledge and opinion were compiled in Table 1. In all the conditions mentioned, however, by no means the pathogenesis of stress-induced lesions could be considered as identical or uniform 
Table 1. Pathological states and stressful conditions associated with acute gastroduodenal lesions

\begin{tabular}{lll}
\hline Condition & Hypothesis tested by & \\
\cline { 2 - 3 } & $\begin{array}{l}\text { Report or review on } \\
\text { animal experiments }\end{array}$ & $\begin{array}{l}\text { Prospective trial or } \\
\text { reliable clinical survey }\end{array}$ \\
\hline Trauma & Friesen et al. [35] & $\begin{array}{l}\text { Bowen and Fleming [11] } \\
\text { Glass and Stremple [37] }\end{array}$ \\
$\begin{array}{l}\text { Major surgery and } \\
\text { postoperative complications }\end{array}$ & Merendino et al. [79] & Weber et al. [111] \\
Cerebral injury & Cushing [19] & Kamada et al. [53] \\
Haemorrhagic shock & Menguy et al. [78] & Goodman and Frey [38] \\
Respiratory insufficiency & Mullane et al. [81] & Skillman et al. [101] \\
Fat embolism & Baronofsky and Wangensteen [5] & Mears [77] \\
Renal insufficiency & Mullane et al. [80] & Fischer and Stremple [29] \\
Infection (sepsis) & Rasche and Butterfield [85] & Le Gall et al. [58] \\
Lucas et al. [70]
\end{tabular}

$[17,19,56,59,77,84,93,102]$. Depending on their combination cimetidine could be effective and harmless in the one patient, but ineffective and harmful in the other. Stratification or a study on several distinct subgroups of patients was considered, but the conditions in Table 1 unfortunately were mixed up in the critically ill patients in a highly irregular way. In addition, for their prevention and treatment about a dozen of drugs was administered to a single patient per day complicating the evaluation of the effects of cimetidine considerably.

(2) Varying time relationships between the numerous conditions in table 1 diminished the precision of the criteria for a patient entering the trial to a critical extent [22]. If for instance "respiratory insufficiency" was the attribute of selection the one patient just had acquired it by a thorax trauma in a car accident, the other by suffering from fat embolism $2-4$ days after the accident, the other by septical complications $10-20$ days after the accident. This was one of the reasons why a trial on stress ulcer prophylaxis by cimetidine could be standardized a little easier than that on treatment [30].

(3) Few and incomplete attempts were found in the literature $[4,54]$ to grade the severity and intensity of the pathological states and stressful conditions (Table 1) with respect to their risk for stress ulceration. It was for instance impossible to decide whether all patients with trauma should obtain cimetidine prophylaxis, or only those with polytrauma or exclusively those with severe polytrauma. This problem would have been of rather minor interest if surgical and severely ill patients would not also be exposed to special risks other than stress ulceration. These could be influenced by cimetidine. For instance, alterations were found within their inmune system [109] which in duodenal ulcer patients very probably is not impaired by cimetidine [57]. But histamine $\mathrm{H}_{2}-$ receptors have been demonstrated in various immunological test systems [108] and it is far from clear which role histamine plays in various life-preserving defense mechanisms of severely ill pa- tients. Furthermore, cerebral disturbances and renal failure which promote stress ulcer formation (Table 1) occur quite regularly in these patients, but may also be elicited by cimetidine [96]. Thus it is by no means justified to distribute the drug to all patients of intensive care units, but only to those who are really at risk for acute ulceration.

(4) Since only surgical and critically ill patients were selected for our trial particular ethical problems arose which opposed a more rigid "scientific" approach [68]. Routine fiberoptic endoscopy for instance was regarded as a safe procedure in patients with uncomplicated gastroduodenal ulcer disease [92], but not in polytraumatized patients suffering from serial costal fractures, serious lung injury, tracheotomy - all these local obstacles associated with shock, hepatic and renal insufficiency and septical complications. For this reason the local ethical committee did not permit us diagnostic endoscopy in any of the patients admitted to trial before clinically manifest gastrointestinal bleeding occurred. Other ethical conflicts will be discussed in the following section.

All these difficulties prompted us to do our best in skilfully designing the trial, but also to alter the plan and conduct of the study at various steps of the performance.

\section{Historical Development of the Trial}

February 1976: Continuing previous studies on histamine and stress uleers $[59,61]$ the first setting of a double-blind randomized controlled trial was produced on cimetidine prophylaxis in patients of the intensive care unit.

100 patients considered at risk (Table 1, [92]) for clinically manifest ulceration (incidence about 20 per cent) should enter the trial running for about $18-24$ months. Six major indications were included [59]: severe burns, severe cerebral injury, severe polytrauma, postoperative complications, major surgery and respira- 
Table 2. Definition of severe polytrauma. (For further comments and conditions see text in Sect. 2.3)

Injury with danger to life and possible physical disability

At least 3 body regions affected

a) 3 body cavities (head, thorax, abdomen)

b) 2 body cavities +1 extremity fracture

c) 1 body cavity +2 extremity fractures

d) 3 extremity fractures

Body cavity =lesions within the body cavity or on its walls

Extremity fracture $=$ fracture of a long bone (humerus, radius, ulna; femur, tibia, fibula)

tory insufficiency, Patients with bleeding abnormalities, history of peptic ulcer, gastric carcinoma, oesophagus and lung resections (problems with endoscopy!) were put in escape.

The regimen of drug administration (cimetidine and placebo) was defined as described in Methods. The randomization list should be performed by the company Smith, Kline and French (SKF) and sets with drug or placebo medication should be delivered to the clinicians by SKF to allow a double-blind design.

The following attributes and parameters were selected and defined: (1) Gastroduodenal ulcerations in patients admitted to trial should be recorded both as clinically manifest and non-clinical lesions. The first ones should be assessed at any time during the treatment period and the rest of hospital stay using emergency endoscopy and - if necessary - X-rays. The second ones should be detected with the aid of two diagnostic endoscopies 5 and 14 days after admission to trial. In the escape group and in all other patients hospitalized during the trial period only climically manifest lesions should be noted. (2) As criteria for the final outcome death or survival should be recorded. (3) Onset and duration of pathological states and stressful conditions (Table 1) should be assessed by standard clinical findings and laboratory tests. (4) The standard programm of clinical-chemical tests for studying new drugs [21] should be applied to the patients in trial and in the escape group. Additionally histamine in plasma and in mucosal biopsies should be determined during the treatment period.

July 1976. Resulting from various meetings the decisions about selecting patients for irial, escape and drop-out were changed and definitely specified (see Table 3 and 4). Instead of 6 only 4 subgroups of severely ill patients were included. In view of the results presented later on in this communication unfortunately the subgroup of "postoperative complications" was eliminated, but the onset of this pathological state (Table 1) was considered as often too vague to allow a precise start with drug application. The subgroup of "major surgery" was eliminated since already from retrospective analysis the incidence of stress ulceration was found to be low in the patients of our clinic. The remaining 4 subgroups were conclusively defined: (1) Severe burns =at least $25 \%$ of the body surface and 2 nd degree (2) severe cerebral injury =unconsciousness for at least 72 hours, (3) severe polytrauma $=$ at least 3 body regions, (4) respiratory insufficiency $=$ controlled respiration for at least 8 hours [30]. From retrospective analysis of 3 yearbooks of the intensive care unit we expected about $20,20,40$ and 40 patients respectively in the 4 subgroups within 18-24 months (total number 120) [30].

December 1976. The definite protocols were submitted to the local ethical committee (SFB 122 of Deutsche Forschungsgemeinschaft) chaired by H. Hensel [47]. For ethical reasons [3] they were enforced to be altered in two important components: (1) A sequential study
Table 3. Escape from trial for patients with severe polytrauma. (For further comments and conditions see text in section 2.3) Informed consent was obtained not only by the patients, but also by their relatives because of the critical situation of their admission

Death before first treatment

Admission to hospital, recognition as candidate for trial, or treatment by cimetidine more than the next day after the incident

No consent to enter the trial

Age less than 18 years

History or clinical evidence of either duodenal or gastric ulcer, atrophic gastritis or gastric carcinoma

History of gastric operations (increased reflux) (93)

Primary bleeding abnormalities

Severe renal or liver insufficiency, or bone marrow disease (decision of the executive group)

Table 4. Drop-out from trial for patients with severe polytrauma. (For further comments and conditions see text in section 2.3)

Stress ulcerations following prophylaxis by placebo

Unreliable drug intake or recede from trial

Failures in treatment pertinent to trial (decision of the executive group)

Transfer to other hospitals within the 2 weeks of prophylaxis

Development of severe renal or liver failure or leucopenia or other signs of bone-marrow damage (decision of the executive group)

Significant reactions reasonable attributable to the drug (decision of the executive group)

was preferred since cimetidine being provided for usually lifethreatening conditions was already theoretically favoured for stress ulcer prophylaxis [76]. The new design had to be worked out separately for the 4 subgroups and the trial was not longer accepted as double-blind, but only as single-blind (at least for the academic staff). For this reason, however, a patient not longer could be excluded from trial by decision of a single physician, but only by that of an executive group. (2) Diagnostic endoscopy was no longer accepted though this procedure was used in several trials in USA [11, 20] and Japan [53]. A harmful effect of endoscopy could not be excluded in the severely-ill patients, especially those with severe polytrauma. Thus only clinically manifest stress ulcerations were selected as the decisive criterion for success or failure of cimetidine prophylaxis and no biopsies could be taken for histamine assays. The finding that no correlation existed between the rates of clinically manifest and non-clinical stress ulcerations [11] was helpful to us to accept this restriction of our trial.

February 1977. The staff of the clinic and especially of the intensive care unit was informed and motivated before the start of the trial. In three sessions of our weekly seminar for training in surgical research [63] questions, design, methods, risks and ethical problems of the trial were discussed with all clinicians and basic research scientists in the Department who finally agreed. In two additional meetings the nurses and technicians of the intensive care unit and the anesthesiologists were informed and convinced in the same way. 
For the trial period an executive group was defined consisting of 6 clinical and 2 theoretical surgeons [63]. It included the 2 academic members of the small working group for stress ulcer [63], the chairmen of the 2 Units, 2 consultants and 2 senior registrars. To reduce observer variation [43] all members of the group had been trained in systematic follow-up [91] and endoscopy during a 3-year prospective trial [92]. The clinical surgeon of the small working group for stress ulcer, M.F., and in his absence the chairman of the prospective study on endoscopy [92], H.R., had to admit the patients to trial in all "clear" cases. In all questionable cases, however, including those for escape or drop-out at least 3 members of the executive group had to agree. Except the chiefsurgeon all 5 clinical surgeons were responsible for a 24 -hour endoscopy service including weekends, holidays etc. After their training they agreed to the same definitions for lesions and bleeding activity but even in night-duty at least two of them had to record and describe the lesions. Blood for plasma histamine assay was taken only by M.F. and in his absence by one of the senior registrars K.H.V., who were especially trained to prepare the plasma under optimum conditions [62].

March 1977. The execution of the trial started on March 15. Because of the expectedly high lethality rate the team met every fortnight to decide whether the trial should be continued or stopped. Furthermore, the staff of the clinic was informed and motivated again and again in our weekly seminar for training in surgical research [63].

Despite all this efforts important events and failures happened in the period of execution which strongly influenced the course of the trial and finally resulted in exclusion of all but one subgroups.

(1) In May 1977 the consultant specialized for burns left the clinic. Many patients with burns, especially those with the more severe lesions, were lost by a shift in hospital admission from Marburg to Giessen. This led to exclusion of subgroup 1 from trial in October 1977 for practical reasons.

(2) In September 1977 a failure in the trial design was detected in subgroup 2. About one week after hospital admission patients with severe head injury as single trauma (Table 6) were transferred to the neurological clinic (drop-out condition 4, Table 4). Those with polytrauma (not severe polytrauma!) remained in subgroup 2. In January 1978 a neurosurgical unit was opened in our clinic. Also patients with severe head injury as single trauma were kept now more or less in our intensive care unit (with some adaptation effect) and more sophisticated surgery was performed in them. Thus in February 1978 subgroup 2 was excluded from trial because of selection bias, critical inhomogenity in combination with a small number of patients.

(3) In March 1978 subgroup 4 had to be excluded from trial - a most regretable decision since already 26 patients had entered the study. However, in executing the trial we became more and more aware of the strongly variable time relationships between respiratory insufficiency and the other pathological states in Table 1 (see theoretical issues). Indeed, the imprecise entrance criteria became apparent by practical difficulties which finally led to the exclusion of the subgroup. Whereas the admissions of patients with severe polytrauma were such dramatic events that they were easily recognized even after one year of trial persistence with all its fading effects two patients with controlled respiration for $12 \mathrm{~h}$ were simply overlooked during a weekend. The anaesthesiologist in duty forgot to announce them, the surgeon of the executive group did not ask rigorously enough. Being sensitized we became aware of similar faults in the past and again suspected a selection bias which led to the exclusion of the subgroup.

All three subgroups excluded from the trial with cimetidine prophylaxis were followed-up among all the other patients admitted
Table 5. Clinically manifest stress ulcerations in all patients of the surgery clinic - a prospective study. All patients with stress ulcerations developped the lesions within the clinic, none of them was included who was admitted or readmitted to hospital for this indication. Time of the trial March 1977-June 1978. Incidence in \% (95\% confidence limits) (two-sided) or $97.5 \%$ (one-sided)

* $0.0(0-0.07) \%$ for all patients being not in the intensive care unit

\begin{tabular}{|c|c|c|c|c|}
\hline \multicolumn{3}{|l|}{ Patients } & \multicolumn{2}{|l|}{ Lesions } \\
\hline Ward & Indication & $\begin{array}{l}\text { Number } \\
\left(n_{1}\right)\end{array}$ & $\begin{array}{l}\text { Number } \\
\left(n_{2}\right)\end{array}$ & $\begin{array}{l}\text { r Incidence } \\
\left(n_{2} / n_{1}\right)[\%]\end{array}$ \\
\hline \multirow{3}{*}{$\begin{array}{l}\text { Intensive } \\
\text { care unit }\end{array}$} & Trauma & 232 & 7 & 3.0 \\
\hline & Others & 848 & 13 & 1.5 \\
\hline & Total & 1,080 & 20 & $\begin{array}{l}1.9 \\
(1.16-2.82)\end{array}$ \\
\hline \multirow[t]{4}{*}{ Casualty } & Single trauma & 701 & 0 & 0.0 \\
\hline & $\begin{array}{l}\text { Polytrauma, } \\
>18 \mathrm{ys}\end{array}$ & 111 & 0 & 0.0 \\
\hline & $\begin{array}{l}\text { Polytrauma, } \\
14-18 \text { ys }\end{array}$ & 13 & 0 & 0.0 \\
\hline & Total & 825 & 0 & 0.0 \\
\hline \multirow{3}{*}{$\begin{array}{l}\text { Children's } \\
(<14 \text { ys) }\end{array}$} & Single trauma & 228 & 0 & 0.0 \\
\hline & Polytrauma & 23 & 0 & 0.0 \\
\hline & Total & 251 & 0 & 0.0 \\
\hline $\begin{array}{l}\text { Other wards } \\
\text { and parts of } \\
\text { the wards }\end{array}$ & Total & 4,478 & 0 & $0.0 *$ \\
\hline $\begin{array}{l}\text { All hospital } \\
\text { admissions }\end{array}$ & Total & 6,634 & 20 & 0.3 \\
\hline
\end{tabular}

to our clinic concerning stress ulceration (Table 5,6) and lethality rate (Table 7).

June 1978. Even for the only remaining subgroup of patients with severe polytrauma the trial was stopped for ethical reasons before the bounderies of the sequential plan were reached. On June 15 when already 28 of these patients had entered the trial the fifth patient in the placebo group started with bleeding from gastric erosions compared to none in the cimetidine group (see also Table 6). After $8 \mathrm{~h}$ the bleeding stopped following therapeutic application of cimetidine, but the patient died at the same day from circulatory insufficiency. Since in the placebo group already two 18 years old patients had died after massive haemorrhagic gastritis under dramatic circumstances all members of the executive group agreed to stop the trial. As an external referee we asked $\mathrm{H}$. Immich, Heidelberg, who confirmed our decision. According to his advice we used the exact test of Fisher (one-sided) [32] for only once testing the null hypothesis and obtained a probability value of $p<0.025$. Thus cimetidine apparently was highly effective in preventing stress ulceration in patients with severe polytrauma.

\section{Methods and Definitions in the Trial Restricted to Severe Polytrauma}

Severe Polytrauma. Two pathophysiological findings had to be considered to find a clinically simple and sufficiently reliable defini- 
Table 6. Clinically manifest stress ulcerations in patients of the intensive care unit from which the patients with severe polytrauma were selected for trial. Patients were admitted to the intensive care unit when their condition was considered life-threatening and additionally in some cases unknown of origin. There were few exceptions which were specified separately. In all cases of stress ulceration reacerbation of a chronic ulcer was excluded by case history, clinical findings and microscopical examination. - Definition of the classes: Single trauma = trauma of life-threatening severity, with complications such as fat embolism (see also [99]), singular cerebral injury ( 68 cases), blunt abdominal trauma ( 22 cases), gunshot injury, stab wound and burns. - Polytrauma was defined with the same terms as severe polytrauma (Table 2), but was only restricted to 2 lesions. - Acute abdomen=ileus, gastro-intestinal bleeding, biliary diseases, pancreatitis etc, --Postoperative complications $=$ wound ruptures and leakages etc. including all further consequences such as peritonitis, renal and respiratory insufficiency etc.

- Patients at risk defined according to Wawersik et al. [110], i.e. with preoperative risks, such as age, lung emphysema etc., but not with trauma or acute abdomen. - Major surgery=total gastrectomy, Whipple's operation, lung resection etc., but without significant postoperative complications. - Respiratory and cardiac insufficiency $=$ patients with these primary diseases not operated upon or developping them in later, usually uncritical phases of the reconvalescence after operation, such as after myocardial ischaemia. - Severe infections = tetanus and sepsis after minor injuries. - Other sporadic indications $=$ endocrine disturbances ( 4 cases), suicidal intents with drugs ( 4 cases), shortage in beds (11 cases) and patients with no definite final diagnoses (73 cases). - The subgroup of 26 patients with respiratory insufficiency admitted to trial (14 treated with cimetidine, 12 with placebo) was included in the classes of "postoperative complications" and "respiratory insufficiency". Since both a patient with postoperative complication (P.C.) and with cimetidine and one with P.C. and placebo developped stress ulcerations, care was not taken to exclude the subgroup from the whole sample. (For further conditions see Methods (section 2.3), incidence in $\%(95 \%$ (two-sided) or $97.5 \%$ (one-sided) confidence intervals)

\begin{tabular}{|c|c|c|c|}
\hline \multicolumn{2}{|l|}{ Patients } & \multicolumn{2}{|l|}{ Lesions } \\
\hline Indication & $\begin{array}{l}\text { Number } \\
\left(n_{1}\right)\end{array}$ & $\begin{array}{l}\text { Number } \\
\left(n_{2}\right)\end{array}$ & $\begin{array}{l}\text { Incidence } \\
\left(\mathrm{n}_{2} / \mathrm{n}_{1}\right)[\%]\end{array}$ \\
\hline Single trauma & 105 & 0 & $\begin{array}{l}0.0 \\
(0-3.45)\end{array}$ \\
\hline Polytrauma & 93 & 2 & 2.2 \\
\hline $\begin{array}{l}\text { Severe polytrauma, } \\
\text { without prophylaxis }\end{array}$ & 14 & 5 & $\begin{array}{l}35.7 \\
(12.76-64.86)\end{array}$ \\
\hline $\begin{array}{l}\text { Severe polytrauma, } \\
\text { with prophylaxis }\end{array}$ & 14 & 0 & 0.0 \\
\hline $\begin{array}{l}\text { Severe polytrauma, } \\
\text { escape }\end{array}$ & 6 & 0 & 0.0 \\
\hline Trauma total & 232 & 7 & 3.0 \\
\hline $\begin{array}{l}\text { Abdomen, acute and } \\
\text { unknown of origin }\end{array}$ & 410 & 3 & 0.7 \\
\hline $\begin{array}{l}\text { Postoperative } \\
\text { complications }\end{array}$ & 83 & 5 & $\begin{array}{l}6.0 \\
(1.98-13.5)\end{array}$ \\
\hline Patients at risk & 111 & 3 & 2.7 \\
\hline Major surgery & 70 & 0 & $\begin{array}{l}0.0 \\
(0-5,13)\end{array}$ \\
\hline Neurosurgical operations & 39 & 0 & $\begin{array}{c}0.0 \\
(0-9.03)\end{array}$ \\
\hline $\begin{array}{l}\text { Respiratory and cardiac } \\
\text { insufficiency }\end{array}$ & 27 & 2 & 7.4 \\
\hline Severe infections & 16 & 0 & 0.0 \\
\hline Other sporadic indications & 92 & 0 & 0.0 \\
\hline Other indications total & 848 & 13 & 1.5 \\
\hline Intensive care unit total & 1,080 & 20 & 1.9 \\
\hline
\end{tabular}

Table 7. Lethality of all traumatized patients of more then 13 years age admitted to hospital. For conditions see Table 5 and text in Methods (2.3). Without prophylaxis=no cimetidine

\begin{tabular}{|c|c|c|c|c|}
\hline \multicolumn{3}{|l|}{ Patients } & \multicolumn{2}{|l|}{ Lethality } \\
\hline Ward & Indication & $\begin{array}{l}\text { Number } \\
\left(\mathrm{n}_{1}\right)\end{array}$ & $\begin{array}{l}\text { Number } \\
\left(\mathrm{n}_{2}\right)\end{array}$ & $\begin{array}{l}\text { Incidence } \\
\left(\mathrm{n}_{2} / \mathrm{n}_{1}\right)[\%]\end{array}$ \\
\hline \multirow{6}{*}{$\begin{array}{l}\text { Intensive } \\
\text { care unit }\end{array}$} & Single trauma & 105 & 12 & 11.4 \\
\hline & Polytrauma & 93 & 16 & 17.2 \\
\hline & Severe polytrauma, without prophylaxis & 14 & 6 & 42.9 \\
\hline & Severe polytrauma, with prophylaxis & 14 & 7 & 50.0 \\
\hline & Severe polytrauma, escape & 6 & 5 & 83.3 \\
\hline & Trauma total & 232 & 46 & 19.8 \\
\hline \multirow[t]{3}{*}{ Casualty } & Single trauma & 701 & 8 & 1.1 \\
\hline & Polytrauma & 124 & 4 & 3.2 \\
\hline & Trauma total & 825 & 12 & 1.5 \\
\hline Total & $\begin{array}{l}\text { Trauma total } \\
\text { (patients more than } 13 \text { years) }\end{array}$ & 1,057 & 58 & 5.5 \\
\hline
\end{tabular}


tion for severe polytrauma: adaptation and cross-adaptation against acute ulcerations by lower stressor activities [88] and a dose-response relationship between incidence of acute ulcerations and severity of each of the pathological states in Table $1[4,54$, 87] above a distinct threshold of stressor activity. Our definition is compiled in Table 2. Other definitions $[4,11,98]$ had also been discussed, but in our opinion suffered from different classes not excluding each other satisfactorily [49]

Fractures of the spinal column were classed with the corresponding body cavities (vertebral region of neck with head, thoracic region with thorax, lumbar and sacral region and pelvis with abdomen). Lesions of retroperitoneal organs and the bladder also were classed with abdominal cavity. The criteria for severe polytrauma were assessed by routine clinical investigations, $\mathrm{X}$-rays and findings at urgent operations. They could be obtained without relevant delay to admit the patients to trial in time (see escape clause).

Escape and Drop-Out Clause (Table 3 and 4). Patients dying before the end of treatment were not considered as drop-outs. On the contrary, survival or death were criteria for success or fallure of treatment. Furthermore patients developing renal or liver insufficiency or leucopenia during treatment could not be excluded automatically (Table 3 and 4) since these had also to be considered as complications of the underlying diseases.

Patients in escape or drop-out should have standard treatment (in our clinic no antacids, of. [12]. They should or should not receive cimetidine according to their consultants opinion (for ethical consequences from assuming the null hypothesis in surgical trials see [68].

Groups Treated by Cimetidine and Regimen of Drug Administration. Except the cimetidine group with severe polytrauma the drug was given for prophylaxis to 1 child in escape (Table 5), 1 patient with severe cerebral injury and 14 patients with respiratory insufficiency (all in dropped-out subgroups). For therapy it was applied to all patients with stress ulcers in our clinic during the trial period including those receiving placebo for prophylaxis. Other patients at risk in our hospital certainly did not receive the drug since cimetidine was not on the market in Germany till a large period of the trial already passed away and candidates for drug delivery were controlled in our gastroenterological unit [91].

The first day after admission was defined as the first day of treatment. Patients coming from midnight till 4 p.m. (end of day duty) received the drug at the same day, those arriving after $4 \mathrm{p} . \mathrm{m}$. till midnight received the drug at $8 \mathrm{a} . \mathrm{m}$. the next morning. Considering the time interval between accident and hospital admission see subgroup 2 in Table 3 (escape). Cimetidine was applied for two weeks mainly for two reasons which had been carefully checked: (1) About 90 per cent of acute gastroduodenal lesions become clinically manifest in the first two weeks after onset of the pathological states in Table $1[11,20,70,77,92]$. (2) Severely ill patients usually stay at least two weeks in our hospital and so remain under our survelllance.

The patients received $1.2 \mathrm{~g} /$ day i.y. for 5 days and thereafter p.o. for 9 days if their physical state was appropriate. Otherwise the drug was continuously applied i.v. till the end of treatment. The single i.v. dose of $200 \mathrm{mg}$ (about $3 \mathrm{mg} / \mathrm{kg}$ ) was given in 4-h intervals by a 2 min injection or infusion [69] starting at 8 a.m. The oral dose was applied as $200 \mathrm{mg}$ tablets at meals under surveillance of the nurses, 2 tablets at breakfast, 1 at lunch and dinner and 2 at bedtime. In renal failure (creatinium more than $2.5 \mathrm{mg} / \mathrm{dl}$ corresp. to $221 \mathrm{nmol} / \mathrm{l}$ ) the dose was reduced to $2 \times 200$ $\mathrm{mg} /$ day ( 8 a.m. and 8 p.m.) which kept the blood level as high as $1.2 \mathrm{~g} /$ day in normal conditions [16]. The usual dose and route of application were chosen considering both efficacy [1, 76] and pharmacokinetics [39].
The drug supply for an individual patient was packed as a set sufficient for two weeks i.v. plus 9 day p.o. treatment. Both drug and placebo were labelled as "Cimetex". They were administered by the nurses and technicians of the ICU who did not know whether the patient received verum or placebo. This "doubleblind" design was necessary because the technical staff had first to announce visible bleeding in cases of stress ulceration (see below).

Clinically Manifest Acute Gastroduodenal Ulceration. Their definition as acute lesions in the gastroduodenal wall which led to visible bleeding and/or perforation was followed by a rather complicated procedure of assessment:

(1) "Clinical manifest": in all the critically ill patients selected for trial routinely a nasogastric tube was inserted for continuous suction at least for one week. Manifest bleeding was detected either by finding visible blood in the gastric aspirate or by recording haematemesis and/or melaena following careful observation of the patients. To detect blood in the aspirate the nurses and technicians additionally were trained and programmed to irrigate the tube in the morning and afternoon. If they detected coffe-ground like haematin or fresh red blood in the aspirate or recorded haematemesis and melaena the clinical surgeon of the executive group in duty was called who personally tested the gastric content or stools and repeated the irrigation. Bleeding was accepted if at least in one of the aspirates blood material could undoubtedly be seen by him. All other clinical signs of acute ulcerations such as fall in blood haemoglobin content, shock or acute abdomen were also definitely assessed only by the clinicians of the executive committee.

All 6,634 patients hospitalized for reasons other than already manifest acute ulceration were carefully observed for clinical signs of upper gastrointestinal bleeding by the staff of the clinic (see previous section). Since, however, continuous suction of gastric contents was not performed in most of them the clinical sign of visible blood in gastric aspirate could not be recorded regularly in this group of patients. The definite assessment of all the other clinical signs again had to be performed by the clinicians of the executive group.

(2) "Acute ulceration": within the next hour after detecting the clinical symptoms of bleeding or perforation urgent endoscopy using a transportable endoscopy unit [105] or X-rays for showing free air in the abdomen were performed in all cases. If lesions were detected they were characterized by assessing their type [90], number, bleeding activity [34], localization and expansion. A photograph was taken via the endoscope. In some cases the lesions were confirmed by surgery.

They were differentiated from lesions caused by the nasogastric tube which showed a typical localization and/or a typical shape (e.g. lengthy at the cardia). A series of biopsies was taken for microscopical examination to show that the lesions observed were acute. All data for the assessment of acute ulceration were recorded by a protocol developed for computer-aided diagnosis as part of the Airdale Multicentre Study on upper gastrointestinal bleeding [1]. For calculating the risk rates for stress ulceration in several groups the total number of patients admitted to hospital was obtained from the admission year books of the clinic administration.

Final Outcome. Death in patients with severe polytrauma, but also in those hospitalized during the trial period was defined in clinical, but not in pathoanatomical terms [51] since consent of the relatives to perform an autopsy could not be expected in most of the patients. Survival was tested til discharge from the surgical clinic or from any other university hospital if the patients at any time after the two weeks treatment in our clinic had to be transfered to them owing to a direct consequence of their accident. This 
occurred in one patient 16 days after the accident for a delayed operation at the E.N.T. clinic. Hospital death was assessed by controlling the year-books of the intensive care unit, the wards of our clinic and the history of the few others transferred to other hospitals by two members of the executive group (M.F. and W.L.) independent of another. Special care was taken that the same subjects were not counted twice because of fluctuations between the intensive care unit and the other wards.

Pathological States and Stressful Conditions (Table 1). The optimum efficiency for predicting these states by ROC curves [72, 73] has never been calculated and very probably is also different for diagnosing their onset and their duration. Thus relatively simple definitions were chosen to acchieve more diagnostic specificity than sensitivity $[36,49,72]$.

(1) Cerebral injury was assessed by case history, clinical methods including the Glasgow scale [103], X-ray examinations including the skull, angiography and occasionally EEG. (2) Haemorhagic shock was assessed by clinical methods, physical and clinical-chemical measurements and was defined according to Allgöwer [2]. Furthermore an arbitrary value of blood-loss was given by recording the number of necessary blood transfusions. (3) Respiratory insufficiency was differentiated into primary and secondary respiratory insufficiency. The first one was defined as already existing at hospital admission, the second one as starting after at least a 3 day interval of normal respiration (no intubation, no artificial respiration necessary) which followed hospital admission or a period of primary respiratory insufficiency. The complication was assessed by clinical findings, measurement of blood gases and $\mathrm{X}$-rays and was defined according to [7] insisting on the repeatedly obtained evidence of a $\mathrm{O}_{2}<60 \mathrm{~mm} \mathrm{Hg}$ when breathing room air. (4) Fat embolism was assessed by case history, clinical findings, clinical chemical tests (mainly blood gases) and X-ray examination. It was, however, especially difficult to define because of the many unspecific symptoms interfering with those of other complications in polytraumatized patients [104]. Thus we followed the definition of Gurd [40] insisting on the evidence of petechial rash, respiratory symptoms plus bilateral signs with positive radiographic changes. (5) Renal insufficiency was assessed by measuring the volume of urine/h and by clinical chemical tests including repeated determination of the creatinium concentration in serum. Especially the last mentioned parameter was used for the decision to reduce the daily cimetidine dose (see before). Acute renal failure was defined by a urine/plasma urea ratio of less than 10 and a urine volume of less than $30 \mathrm{ml} / \mathrm{h}$. (6) Septical complications were assessed by clinical findings, elevated body temperature, performing serial blood cultures and recording the effects of antibiotics. They were defined according to LeGall et al. [58] by positive blood cultures and diagnosis of the initial septic focus. (7) Immobilization was registered if a wire extension was performed or if the gypsum cast covered at least two of the extremities. Finally, the application of "ulcerogenic" drugs was documented both in the trial protocol plus in the case history of each of the patients.

Standard Program of Clinical-Chemical Tests for Studying New Drugs [21]. This was performed on day 1, 5 and 14 of the trial, parallel to assays of the plasma histamine levels. The time intervals were chosen since at the first day elevated plasma histamine levels were expected as a consequence of trauma, shock, operations, infusions etc. $[61,62]$. The highest incidence of clinically manifest uicerations was usually observed around the fifth day after the accident and the histamine level at the fourteenth day was considered as a reasonable control value which could be obtained without too many difficulties. Since only very small alterations of the plasma histamine concentrations were expected to be measured $[61,62]$, a more sensitive assay than at present available [60] had to be developed. There are only preliminary reports on this assay till now $[66,67]$, but it will be published in all details in this

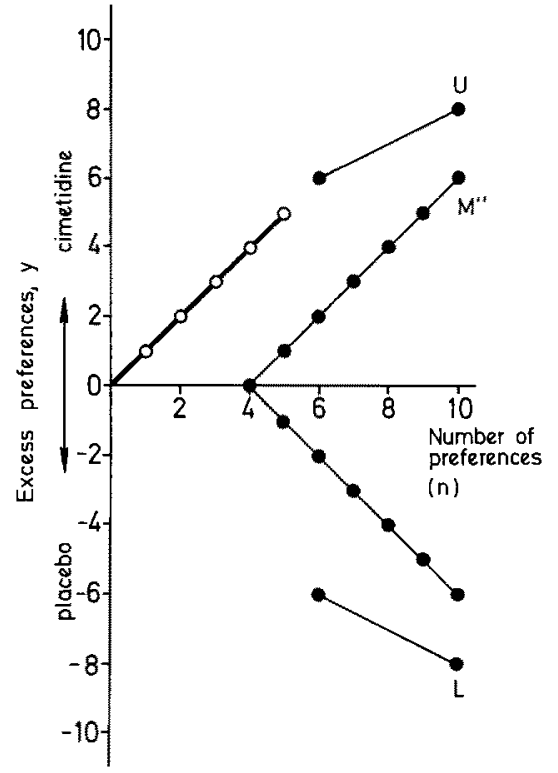

Fig. 1. RST plan for the sequential clinical trial comparing cimetidine and placebo for prophylaxis of stress ulceration in patients with severe polytrauma. Two-sided overall significance level $2 \alpha=$ 0.05 , power $1-\beta=0.95$, critical value $\theta=0.95$ [3]. The bold line shows the progress in trial. It was stopped before the upper boundery was reached. For explanation see text in Statistics. $\mathrm{U}=$ upper boundery, $\mathrm{L}=$ lower boundery, $\mathrm{M}^{\prime \prime}=$ modified middle boundery [3]

series of communications. Furthermore it was considered essential to take blood samples always at the same time of the day $(7,30-8.00$ a.m.) and because of histamine release always before the frrst cimetidine application on that particular day [69]

\section{Statistics}

Generally the $95 \%$ confidence intervals (two-sided) were estimated for the incidences of stress ulceration in several groups of patients in our Surgery Clinic [49]. Only in cases where the incidence was zero the $97.5 \%$ confidence interval (one sided) was calculated $\left(P_{x}=\right.$ 1 -antilog $(\log \alpha / \mathrm{N}))$ [36a]. Regarding these values and with respect to the prospective sampling of our data some comparative rates ("risk rates") were calculated for reasonable large sample sizes according to Cornfield (17a) (see also [50]). Enforced by our ethical committee for significance testing an appropriate RST plan [3] was constructed for sequential experimentation (Fig. 1). Randomization was performed in blocks of 4 patients [3]. It was asșumed from literature (Table 1) and from our data in the prospective study [92] that in severe polytrauma the incidence of stress ulcerations would be about 30 per cent using placebo $\left(\pi_{1}\right)$. If cimetidine was expected to be highly effective (see introduction) in a sample af about 50 patients the smallest incidence of stress ulceration would be reasonably predicted as about 2 per cent $\left(\pi_{2}\right)$. Choosing a critical value $\theta=0.95$, an overall significance level $(2 x)=0.05$ and a power $(1-\beta)=0.95$ the number of preferences in the RST plan would be maximum 10 corresponding to maximum 66 patients if $\phi$ would be 0.31 . The average sample number (ASN) in these conditions would be 6.8 preferences corresponding to 44 patients [3]. Since the stopping rule based on repeated two-sided significance tests, a nominal significance level $2 \alpha$ less than 0.05 had to be chosen and was 0.0313 in our plan (Fig. 1).

After stopping the trial for ethical reasons the exact test of Fisher [32] was used for testing significance in the sample of patients with severe polytrauma. 


\section{Results}

\section{Incidence of Stress Ulcerations in the Patients of the Marburg Surgery Clinic}

The Surgery Clinic in Marburg with 170 beds is situated in a city of 60,000 inhabitants surrounded by rural areas in North Hessia. It has the function of a district hospital since in a circumference of about $40 \mathrm{~km}$ no other surgery clinic of a reasonable size and of appropriate medical facilities can be found. These conditions are very favourable for drawing conclusions from findings in our trial sample to those on the corresponding target population.

However, some other factors which are less common may have influences on our clinic population. For instance we have an excellent cooperation with the Medical Clinic including common seminars for treatment of difficult cases. Thus it cannot be excluded that especially in abdominal diseases as the main interest of the two units some of the incidences for stress ulceration are biased by hospital admission [8]. Also the introduction of highly qualified neurosurgery from Giessen into our clinic in Marburg may have positively influenced the results. Finally during social analysis of our sample we become aware of the fact that North Hessia contains a higher proportion of refugees and foreign workers than other federal countries.

Taking into account these pecularities nevertheless we drew some cautious conclusions. The overall incidence of clinically manifest stress ulcerations in patients hospitalized in the Surgery Clinic was $0.3 \%$ (Table 5). This was about 5-times lower than the incidence of ileus or the prevalence of chronic duodenal ulcer in our hospital population [92] and may therefore be considered as rather low.

The occurrence of acute upper gastrointestinal lesions, however, was not uniformly distributed over the various wards and units. Using the confidence intervals (see section Statistics) the incidence of stress ulceration was $1.9(1.16-2.82) \%$ in the intensive care unit, but $0(0-0.07) \%$ in all other parts of the hospital (Table 5). This significant and important difference enforced us to look for further specification of the groups at risk for stress ulceration.

\section{Incidence of Stress Ulcerations in Various Groups of Patients in the Intensive Care Unit}

Also in the intensive care unit the risk for stress ulceration was not uniformly distributed (Table 5 and 6 ).

In single trauma, even complicated by fat embolism, no bleeding occurred in the trial period (incidence $0(0-3.45))$. In patients with polytrauma, both in the casualty ward and intensive care unit (Table 5 and 6 ), the incidence of stress ulceration was fairly low $(0.98(0.12-3.51) \%)$, but extremely high in the patients with severe polytrauma as defined in this study $(35.7(12.76-64.86) \%)$. The risk rate was calculated $[17 \mathrm{a}]$ to be 35 -times higher in patients with severe polytrauma than in those with (only) polytrauma which clearly destined this group for trial in stress ulcer prophylaxis. However, in single trauma and also largely in polytrauma any kind of special stress ulcer prophylaxis (antacids, somatostatin, secretin, vagolytic drugs or $\mathrm{H}_{2}$-receptor antagonists) seems unnecessary which strongly contradicts common practice in this country.

In non-trauma patients in the intensive care unit (Table 6) rather surprising results were obtained if the reports in the literature (Table 1) were compared to them. Major surgery $(0(0-5.13) \%)$ and neurosurgical operations $(0(0-9.03) \%)$ were not afflicted with a high risk of stress ulceration whereas postoperative complications (anastomotic insufficiency, peritonitis etc.) were associated such with a remarkable incidence of acute lesions as $6(1.98-13.5) \%$. The series of patients investigated in this prospective trial clearly is not large enough to permit a reliable calculation of all the comparative rates for stress ulceration which would be interesting for the clinicians. Since, however, for instance major surgery per se did not increase the risk of upper gastrointestinal bleeding, but only in combination with postoperative complications, these data already demand a new and more appropriate definition and classification of patients at risk for stress ulceration. Only by this a specific prophylaxis can be inaugurated instead of distributing any drug with all its side-effects over the intensive care unit for treatment of so critically ill patients.

\section{Death Rates in Various Groups of Trauma Patients}

To facilitate some conclusions from the sample of our patients to the target population of patients admitted to centres with accidental surgery the death rates were considered as especially useful (Table 7) because of their relationship to the severity of the diseases. In this respect it was quite remarkable how much the death rates were in agreement with those of other centres in Germany which are particularly specialized for accident surgery $[27,99]$.

\section{Comparison of Attributes in Patients with Severe Polytrauma}

Concerning all the pathological states and stressful conditions (Table 1) the cimetidine group of patients 
with severe polytrauma was in excellent agreement to the placebo group. Only the number of immediate operations was 9 in the cimetidine group, but only 5 in the placebo group. All other details of these two subgroups will be published in the second communication [31].

\section{Discussion}

A meticulous description of methodological details is critical for an article both with respect to readers and authors. Much time is necessary to find the way through all the pages, and the large size probably will deter many people from coming to terms with this communication. A sophisticated and (possibly) competitive scientist will find so many branchings of the decision tree that he is rather urged to prepare a list of all those occasions where he would like to elect just that condition which has been rejected in the design of this trial. If any detail, however, is missed by the reader he may suspect with more justification that it has been overlooked in conducting the trial than in the many articles today which enumerate "facts" and torment the fantasy of critical readers with assumptions how probably the findings were obtained.

Nevertheless we have chosen this risk for several reasons:

(1) in clinical science data usually are not as reproducible as in enzymology or analytical chemistry since conditional and interfering factors as well as all their combinations are extremely more numerous in clinical trials than in laboratory experiments. But how should readers and authors have even the slightest chance of a possibility to explain agreements or (usually more often) disagreements of results obtained from clinical trials if we do not describe or define as skilfully as possible all those conditions in our study which at any time came to our mind? This article is an attempt to reconcile the flagrant contradiction that in thousands of clinical studies and dozens of randomized controlled trials where much more conditions have to be considered than in experiments in vitro less scruting in description is observed than in any article published in Journal of Biological Chemistry.

(2) Basic research scientists including several statisticians have recommended very strict and rather idealized rule for clinical research. Others have warned the community that controlled clinical trials are too difficult to execute. Clinical researchers, however, especially in the field of gastroenterology have produced the impression by publishing numerous papers on controlled clinical trials that it is relatively easy to conduct such studies. In our opinion none of these "experiences" is adequate to the problem.
Again the report on our trial should be an attempt to emphasize that controlled clinical trials can be superior to other "designs" of clinical research, but should never be expected to be perfect. They are laborious, time-consuming and - like the life itself - never completely calculable, especially with respect to future, but they are not too difficult to conduct. In our opinion many "well-done" controlled randomized double-blind trials with their superficial presentation have harmed this very valuable idea and have created many of the ethical controverses which in this country arose in the last few years [14a].

As a special point the deviations from the usual structure of an original communication should be discussed. To elucidate the background of the design of a rather complex clinical trial an introduction was considered to be too short and not informative enough. Thus a section of "theoretical aspects" was introduced. The historical aspects of the study were put into a separate section since it was important both for the design and the execution of the project. From a statistical point of view it is by no means justified to assume that a drop-out of subgroups or change in the medical staff (neurosurgeon) had no consequences for the outcome of the trial. We know that it is common use to conceal such changes in the conditions of a "clinical experiment", but in our experience and in our knowledge about "successful" clinical trials around the world it happens so often - and why should its influence on the data in trials not carefully be investigated and confessed. It is in the hands of conductors of clinical trials themselves to convince or make ashamed their critics by their courage for truth and modesty. Finally in the design of the trial there were so many decisions which by other investigators would have been made just into the opposite direction. The article would have been cut to not yet readable pieces of all the decisions would have been explained so much later on in a separate section of the discussion. It was our purpose to perform an experiment on controlled clinical trials - if it stimulates the discussion then it has hit the mark.

Acknowledgement: We are very grateful for adrice and stimulating discussions to H. Immich, B. Schöning (Heidelberg), H. Hamelmann (Kiel), W. Creutzfeldt, B. Clowdus and H.D. Becker (Göttingen), H. Barth (Marburg), F.T. de Dombal (Leeds), M.J.R. Healy, P. Smith, J.W. Black and J.H. Baron (London).

\section{References}

1. Airdale multicentre trial (1976) Analysis of patients with upper gastrointestinal bleeding (chairman and coordinator: FT deDombal), protocol of trial, Leeds

2. Algöwer M (1976) Schock. In: Allgemeine und spezielle Chirurgie. Springer, Berlin Heidelberg New York, p 44 
3. Armitage P(1975) Sequential medical trials. Blackwell Scientific Publications, Oxford London

4. Baker SP, O'Neill B, Haddon W Jr, Long WB (1974) The injury severity score: A method for describing patients with multiple injuries and evaluating emergency care. J Trauma $14: 187-196$

5. Baronofsky ID, Wangensteen OH (1945) The experimental production of erosion or ulcer (gastric and/or duodenal) by the intravenous injection of small amounts of fat in animals. Bull Am Coll Surg 30:59

6. Bauer H, Doenicke A, Holle F (1977) Kasuistische Mitteilung über Möglichkeiten der Prophylaxe und Therapie gastrointestinaler Blutungen mit Cimetidin oder Somatostatin bei Schwerstkranken. Anesthesist 26:662-664

7. Bergmann H, Necek St (1977) Die Beatmung. In: Benzer H, Frey R, Hügin W, Mayrhofer O (eds) Lehrbuch der Anaesthesiologie, Reamination und Intensivtherapie. Springer, Berlin Heidelberg New York, pp 322-348

8. Berkson J (1946) Limitations of the application of fourfold table analysis to hospital data. Biometrics $2: 47-53$

9. Black JW, Duncan WAM, Durant CJ, Ganellin CR, Parsons ME (1972) Definitions and antagonism of histamine $\mathrm{H}_{2}$-receptors. Nature (London) 236:385-390

10. Bonfils S, Rossi G, Liefooghe G, Lambling A (1959) "Ulcère" experimental de contrainte du rat blanc. Rev Franc Etud Clin Biol 4: 146-150

11. Bowen JC, Fleming WH (1974) A prospective study of stress ulceration in Vietnam. Southern Med J 67:156-160

12. Brooks D (1978) Gastrointestinal bleeding in acute respiratory failure. Br Med J I: 922-923

13. Bubrick MP, Wetherille RE, Onstad GR, Andersen RC, Hitchcock CR (1978) Control of acute gastroduodenal hemorrhage with cimetidine. Surgery $84: 510-518$

14. Bugajski J, Hano J, Danik L (1976) Effect of metiamide, a histamine $\mathrm{H}_{2}$-receptor antagonist on the development of gastric stress ulcers and acid secretion. Eur J Pharmacol $36: 237-240$

14a. Burkhardt R, Kienle G (1978) Controlled clinical trials and medical ethics. Lancet 2:1356-1359

15. Burland WL, Simkins MA (1977) Cimetidine. Proc 2nd Intern Symp on Histamine $\mathrm{H}_{2}$-Receptor Antagonists, London. Excerpta Medica, Amsterdam Oxford, pp 1-392

16. Canavan JSF, Briggs JD (1977) Cimetidine clearance in renal failure. In: Cimetidine, Proc 2 ad Int Symp on Histamine $\mathrm{H}_{2-}$ Receptor Antagonists. Excerpta Medica, Amsterdam Oxford, pp 75-80

17. Clarke JS, Coulson WF, Guth PH, Gray RK, Schwabe AD, Ashley FL, Batzdorf U (1972) Gastroduodenal stress ulcers. Calif Med 116:32-46

17 a. Cornfield $J$ (1956) A statistical problem arising from retrospective studies. In : Neyman J (ed) Berkeley Symp on Mathem Statistics and Probability IV. Univ of California Press, Berkeley, pp 135-148

18. Creutzfeld W, Arnold R (1978) Cimetidine. Proc Intern Symp on Histamin $\mathrm{H}_{2}$-receptor Antagonists, Göttingen. Excerpta Medica, Amsterdam Oxford, pp 1-351

19. Cushing $H$ (1932) Peptic ulcers and the interbrain. Surg Gynec Obstet $55: 1-34$

20. Czaja AJ, Mc Alhany JC, Pruitt BA (1974) Acute gastroduow denal disease after thermal injury. New Engl I Med $291: 925-929$

21. Delbrück $A$ (1978) Empfehlungen der Deutschen Gesellschaft für Klinische Chemie zur Durchführung klinisch-chemischer Untersuchungen bei der Prüfung von Arzneimitteln. J Clin Chem Clin Biochem 16:459-462

22. Devroede GI, Taylor WF, Greenstein AJ, Janowitz HD (1979) Natürlicher Verlauf einer Krankheit: Berechnungen und Fehlermöglichkeiten. Chirurg $50: 297-307$
23. Di Pasquale G, Welaj P (1973) Ulcerogenic potential of indomethacin in arthritic and non-arthritic rats. J Pharm Pharmac $25: 831-832$

24. Dunn DH, Silvis S, Onstad G, Fischer R, Howard RJ, Delaney JP (1977) The treatment of hemorrhage gastritis with the H-2 blocking antihistamine, cimetidine. Gastroenterology $72: 1053$

25. Dykes PW, Kang JY, Hoare A, Hawkins CF, Mills JG (1977) Treatment of upper gastrointestinal haemorrhage with cimetidine. In: Cimetidine. Proc 2nd Intern Symp on Histamine $\mathrm{H}_{2}$-receptor Antagonists, London. Excerpta Medica, Amsterdam Oxford, pp 337-344

26. Dykes PW, Hoare A (1978) Treatment of upper gastrointestinal haemorrhage with cimetidine. In: Cimetidine. Proc Intern Symp on Histamine $\mathrm{H}_{2}$-receptor Antagonists, Göttingen. Excerpta Medica, Amsterdam Oxford, pp 271-276

27. Ecke H (1978) Verletzungen des knöchernen Skeletts beim Polytraumatisierten. Chirurg 49:727-730

28. Feller I (1969) Intern Bibl on Burns. Am Burn Research Corporation, Braun Brunfield Ine, pp 183-190

29. Fischer RP, Stremple JF (1972) Stress ulcers in posttraumatic renal insufficiency in patients from Vietnam. Surg Gynec Obstet $134: 790-794$

30. Fischer M, Lorenz W, Reimann HJ, Troidl H, Rohde H, Schwarz B, Hamelmann H (1978) Cimetidine prophylaxis of acute gastroduodenal lesions in patients at risk. In: Cimetidine, Proc Intern Symp on Histamine $\mathrm{H}_{2}$-receptor Antagonists, Göttingen. Excerpta Medica, Amsterdam Oxford, pp $280-290$

31. Fischer M, Lorenz W, Rohde H, Troidl H Prophylaxis of clinically manifest stress ulcerations by cimetidine in patients with severe polytrauma (in preparation)

32. Fisher RA (1970) Statistical methods for research workers. Hafner Press, New York London, pp 96-97

33. Fordtran JS, Grossman MI (1978) 3rd Sympos on Histamine $\mathrm{H}_{2}$-receptor Antagonists: clinical results with cimetidine. Gastroenterology 74:337-488

34. Forrest JAH, Finlayson NDC, Shearman DJC (1974) Endoscopy in gastrointestinal bleeding. Lancet 2:394-397

35. Friesen SR, Merendino KA, Baronofsky ID, Mears FB, Wangensteen OH (1948) The relationship of bone trauma to the development of acute gastroduodenal lesions in experimental animals and in man. Surgery 24:134-159

36. Galen RS, Gambino SR (1975) Beyond normality: The predictive value and efficiency of medical diagnoses, John Wiley \& Sons, New York, pp 30-40

36a. Geigy JR AG (1975) Wissenschaftliche Tabellen-Documenta Geigy (Diem K, Lentner C, Red), Georg Thieme, Stuttgart pp $186-188$

37. Glass GBJ, Stremple JF (1973) Stress ulcers. Lancet $1: 1506-1507$

38. Goodman AA, Frey CF (1968) Massive upper gastrointestinal hemorrhage following surgical operations. Ann Surg $167: 180-184$

39. Griffiths R, Lee RM, Taylor DC (1977) Kinetics of cimetidine in man and experimental animals. In: Burland, WL, Simkins MA (eds) Cimetidine. Proc 2nd Intern Symp on Histamine $\mathrm{H}_{2}$-Receptor Antagonists. Excerpta Medica, Amsterdam, pp $38-51$

40. Gurd AR (1970) Fat embolism: An aid to diagnosis. J Bone \& Joint Surg 52 B: $732-737$

41. Guth PH, Code CF (1978) Histamine release and gastric mucosal damage. Gastroenterology $74: 622-623$

42. Gyr K, Kayasseh L, Meyer FD, Stalder GA (1978) Somatostatin and cimetidine in gastroduodenal haemorrhage. Preliminary report. In: Cimetidine. Proc Intern Symp on Histamine $\mathrm{H}_{2}$-receptor Antagonists, Göttingen. Excerpta Medica, Amsterdam Oxford, pp 299-303 
43. Hall R, Horrocks JC, Clamp SE, DeDombal FT (1976) Observer variation in assessment of results of surgery for peptic ulceration. Br Med J I:814-816

44. Harris SK, Bone RC, Ruth WE (1977) Gastrointestinal hemorrhage in patients in a respiratory Intensive Care Unit. Chest $72: 301-304$

45. Hartmann FW (1945) Curling's ulcer in experimental burns. Ann Surg 121:54-64

46. Harvengt C, Deschepper PJ, Bogaert R, Cremer M, Sharpe PC (1978) Cimetidine (Tagamet). Proc National Symp Brussels. Excerpta Medica, Amsterdam Oxford, pp 1-167

47. Hensel H (1979) Gewinnung von Erkenntnissen in der experimentellen Medizin. In: Pluralität in der Medizin. Der geistige und methodische Hintergrund. Symp Med Pharmazeut Studiengemeinschaft, Titisee (in press)

48. Holle F (1944) Stress ulcerations in soldiers immobilized by an extended gypsum cast. (Submitted for publication)

49. Immich H (1974) Medizinische Statistik. Schattauer, Stuttgart New York, pp 67-71

50. Immich H (1979) Assoziation zwischen Reserpin-Medikation und Brustkrebs? Dtsch Ärztebl, S 29972999

51. Janssen W, Naeve W (1975) Der plötzliche Tod aus natürlicher Ursache. In: Müller B (ed) Gerichtliche Medizin, Part 1, 2nd ed. Springer, Berlin, Heidelberg, New York, pp 248-304

52. Jones RH, Rudge CJ, Bewick M, Parsons V, Weston MJ (1978) Cimetidine: prophylaxis against upper gastrointestinal haemmorhage after renal transplantation. $\mathrm{Br}$ Med $\mathrm{J}$ I: $398-400$

53. Kamada T, Fusamoto H, Kawano S, Noguchi M, Hiramatsu K, Masuzawa M, Saton N (1977) Acute gastroduodenal lesions in head injury. Am J Gastroenterol 68:249-253

54. Kamada T, Fusamoto $H$, Kawano $S$, Noguchi $M$, Hiramatsu K, Masuzawa M, Abe H, Fujil C, Sugimoto T (1977) Gastrointestinal bleeding following head injury: A clinical study of 433 cases. I Trauma 17:44-47

55. Kapp F, Baerlocher Ch, Fahrländer H (1974) Die akuten Magen-Darm-Blutungen. Eine einjährige prospektive Studie. Schweiz Med Wochenschr 104:1609-1613

56. Katz D, Siegel HI (1968) Erosive gastritis and acute gastroduodenal mucosal lesions. Progr Gastroenterol 1:67-96

57. Kruss DM, Littman A (1978) Safety of cimetidine. Gastroenterology $74: 478-483$

58. LeGall JR, Mignon FC, Rapin M, Redjani M, Harari A, Bader JP, Soussy CJ (1976) Acute gastroduodenal lesions related to severe sepsis. Surg Gynec Obstet 142:377-380

59. Lorenz W, Feifel G (1970) Neue Gesichtspunkte zur Pathogenese des StreB- und Steroidulkus. Dtsch Med Wochenschr $95: 1848-1850$

60. Lorenz W, Reimann H-J, Barth H, Kusche J, Meyer R, Doenicke A, Hutzel M (1972) A sensitive and specific method for the determination of histamine in human whole blood and plasma. Hoppe-Seyler's Z Physiol Chem 353:911-920

61. Lorenz W, Seidel W, Doenicke A, Tauber R, Reimann H-J, Uhlig R, Mann G, Dormann P, Schmal A, Häfner G, Hamelmann $H$ (1974) Elevated plasma histamine concentrations in surgery: Causes and clinical significance. Klin Wochenschr $52: 419-425$

62. Lorenz W (1975) Histamine release in man. Agents Actions $5: 402-416$

63. Lorenz W, Hamelmann H, Troidl H (1976) Marburg experiment on surgical research: A five-year's experience on the cooperation between clinical and theoretical surgeons. Klin Wochenschr 54:927-936

64. Lorenz W, Troidl H, Barth H, Rohde H (1978) Histamine, gastric secretion and peptic ulcer disease: An attempt to define special sources of error and problems in clinical-biochemical trials. In: Creutzfeldt, W (ed) Cimetidine, Proc Intern Symp on Histamine $\mathrm{H}_{2}$-Receptor Antagonists, Göttingen. Excerpta Medica, Amsterdam Oxford, pp 6-36

65. Lorenz W, Reimann H-J, Fischer M (1978) Pathogenese der akuten gastroduodenalen Läsion ( "Stressulkus"). In: Blum AL, Siewert JR (eds) Ulcus-Therapie. Springer, Berlin Heidelberg New York, pp 50-62

66. Lorenz W, Doenicke A (1978) Anaphylactoid reactions and histamine release by intravenous drugs used in surgery and anaesthesia. In: J Watkins, Ward MA (eds) Adverse response to intravenous drugs. Academic Press, London, pp 83-112

67. Lorenz W, Schöning B, Schwarz B, Neugebauer E (1978) Increase in sensitivity of the fluorometric plasma histamine determination: Routine assay in the femtomol range. NaunynSchmiedeberg's Arch Pharmacol Suppl to Vol 302:R 63

68. Lorenz W, Rohde H (1979) Prospective controlled clinical trials in surgery. Controversial issues in motivation and performance. Klin Wochenschr 57:301-310

69. Lorenz W, Doenicke A, Schöning B, Mamorski J, Weber D, Hinterlang E, Schwarz B, Neugebauer E (1980) $\mathrm{H}_{1}+\mathrm{H}_{2}$-receptor antagonists for premedication in anaesthesia and surgery: A critical view basing on randomized clinical trials with Haemaccel and various antiallergic drugs. Agents Actions (in press)

70. Lucas Ch, Sugawa Ch, Riddle J, Recter F, Rosenberg B, Walt AJ (1971) Natural history and surgical dilemma of "stress" gastric bleeding. Arch Surg 102:266-273

71. Lucchelli PE (1978) Cimetidina -farmacologia e clinica. Smith Kline and French, SpA Milano, pp 1-309

72. Lusted LB (1968) Introduction to medical decision making. ChC Thomas, Springfield Ill, pp 98-140

73. Lusted LB (1976) Clinical decision making. In: de Dombal FT, Gremy F (eds) Decision making and medical care. NorthHolland Publishing Comp, Amsterdam, pp 77-98

74. McCracken MD, Calton WW, Tuite I (1974) Penicillin viridicatum mycotoxicosis in the rat. III. Hepatic and gastric lesions. Fd Cosmet Toxicol 12:99-105

75. Mac Donald AS, Steele BJ, Bottomley MG (1976) Treatment of stressinduced upper gastrointestinal haemorrhage with metiamide. Lancet $1: 68-70$

76. Mac Dougall BRD, Bailey RJ, Williams R (1977) $\mathrm{H}_{2}$-receptor antagonist and antacids in the prevention of acute gastrointestinal haemorrhage in fulminant hepatic failure. Lancet 1:617-619

77. Mears FB (1953) Autopsy survey of peptic ulcer associated with other disease. Surgery $34 ; 640-654$

78. Menguy R, Desbaillets L, Masters YF (1974) Mechanism of stress ulcer: Influence of hypovolemic shock on energy metabolism in the gastric mucosa. Gastroenterology 66:46-55

79. Merendino KA, Litow SS, Armstrong WD, Wangensteen $\mathrm{OH}$ (1945) The experimental production of erosions or ulcer (gastric and/or duodenal) in animals by fracture or curettement of bone matrow. Bull Am Coll Surg 30:58

80. Mullane JF, Wilfong RG, Phelps ThO, Fischer RP (1973) Metabolic acidosis, stress, and gastric lesions in the rat. Arch Surg 107:456-459

81. Mullane JF, Smith JC, Wilfong RG (1973) Hypoxia and stress ulcer formation in the rat. Surgery $74: 326-332$

82. Mühe E, Gentsch $\mathrm{H}-\mathrm{H}$, Groitl H, Hager Th (1977) Clinical experience in the treatment of massive stress ulcers with cimetidine. In: Cimetidine (Tagamet), Proc Nation Symp Brussels. Excerpta Medica, Amsterdam, pp 138-143

83. Paré WP (1972) Conflict duration, feeding schedule, and strain differences in conflict-induced gastric ulcers. Physiol and Behavior 8:165-171

84. Rainsford KD (1975) The biochemical pathology of aspirininduced gastric damage. Agents Actions 5:326-344 
85. Rasche R, Butterfield WC (1974) The effect of sepsis on acute gastric ulcerations in the rat. Surgery 76:764-770

86. Rees WDW, Rhodes J, Wheeler MH, Meek EW, Williams B, Newcombe RG (1977) Effect of histamine receptor antagonists on bile damage to the gastric mucosa of canine Heidenhain pouches. Gut 18:821-826

87. Reimann H-J, Fischer M, Reich M, Lorenz W (1977) Akute Magenläsionen und Veränderungen des Histamingehaltes verschiedener Organe beim ImmobilisationsstreB. Langenbecks Arch Chirurgie, Suppl Chir Forum, pp 217-220

88, Reimann H-J, Meyer HJ, Schmal A, Fischer M, Lorenz W (1977) Adaptation und Kreuzadaptation an Kälte und Restraint zur Vermeidung von StreBulkusbildung bei der weiblichen Ratte. Z Physik Med 6:22-23

89. Robert A, Nezamis JE (1958) Ulcerogenic property of steroids. Proc Soc Exp Biol Med 99:443-447

90. Roesch W, Otteajann R (1970) Gastric erosions. Endoscopy 2:93-98

91. Rohde H, Troidl H, Lorenz W (1977) Systematic follow-up: A concept for evaluation of operative results in duodenal ulcer patients. Klin Wochenschr 55:925-932

92. Rohde H, Troidl H, Lorenz W, Fischer M, Vestweber KH (1978) Neue Ansätze zur Frage: Hat die Notfallendoskopie für den Chirurgen Bedeutung? Med Klin $73: 773-780$

93. Roth JLA (1974) Drug-induced Lesions of the Stomach. In: Bockus HL (ed) Gastroenterology. Saunders, Philadelphia, pp 487-514

94. Salvini P, Quatrini M, Piodi L, Bianchi P (1978) Trattamento con cimetidina delle emorragie del tratto gastroenterico superiore. In: Lucelli PE (ed) Cimetidina. SKF-Report, Milano, pp 191-198

95. Sawrey WL, Conger JJ, Turrell ES (1956) An experimental investigation of the role of psychological factors in the production of gastric ulcers in rats. $J$ Comp Physiol Pychol $49: 457-461$

96. Schentag JJ, Calleri G, Rose JQ, Cerra FB, De Glopper E, Bernhard H (1979) Pharmacokinetic and clinical studies in patients with cimetidine - associated mental confusion. Lancet $1: 177-181$

97. Schumpelik V, Rauchenberger B (1976) Duodenogastraler Reflux und Streßulkus. Dtsch Med Wochenschr 101:1647-1649

98. Schweiberer L, Saur K (1974) Pathophysiologie der Mehrfachverletzung: Einleitung. Langenbecks A.rch Chir 337:149-156

99. Schweiberer L, Dambe LT, Klapp (1978) Die Mehrfachverletzung: Schweregrad und therapeutische Richtlinien. Chirurg 49:608-614

100. Seufert M (1978) Tierexperimentelle Untersuchungen $\mathrm{zu}$ Pathogenese, Prophylaxe und Therapie sog. "Stressulcera" des Magens. Thesis, University of Heidelberg

101. Skillman JJ, Bushnell LS, Goldman H, Silen W (1969) Respiratory failure, hypotension, sepsis and jaundice - A clinical syndrome associated with lethal hemorrhage from acute stress ulceration of the stomach. Am J Surg 117:523-530

102. Skillman JJ, Silen W (1972) Stress ulcers. Lancet II : 1303-1306

103. Teasdale G, Jennet B (1974) Assessment of coma and impaired consciousness: a practical scale. Lancet 2:80-84

104. Thomas JE, Ayyar DR (1972) Systemic fat embolism. A diag. nostic profile in twenty-four patients. Arch Neurol 26:517-523

105. Troidl $H$, Lorenz $W$, Rohde $H$, Häfner $G$, Ronzheimer $M$ (1976) Histamine and peptic ulcer: a prospective study of mucosal histamine concentration in duodenal ulcer patients and in control subjects suffering from various gastrointestinal diseases. Klin Wochenschr 54:947-956

106. Troidl H, Rohde $H$, Lorenz $W$, Häfner $G$, Hamelmann $H$ (1978) Effect of selective gastric vagotomy on histamine concentration in gastric mucosa of patients with duodenal ulcers. Br J Surg 65:10-18

107. Urcinoli R, De la Pierre M, Guidetti CS (1978) L'impiego della cimetidina nelle emorragie gastriche e duodenali nel paziente neurochirurgico. In: Lucchelli PE (ed) Cimetidina. SKF Report, Milano, pp 209-216

108. Van Dijk H, Rapis M, Jacobse-Geels HEL, Willers JMN (1979) Histamine-2 receptor-mediated immunomodulation in the mouse. Clin Exp Immunol 35:470-477

109. Walton B (1978) Anaesthesia, surgery and immunology. Anaesthesia $33: 322-348$

110. Wawersik J (1970) Datenverarbeitung in der Anaesthesie am Beispiel eines dokumentationsgerechten Narkoseprotokolls. Z Prakt Anästh 5:6-28

111. Weber E, Akorbiantz A, Landolt M, Koeltz HR, Nussbaumer U, Peter P, Blum AL (1977) Prospektive Studien über die postoperative Stressblutung. Dtsch Med Wochenschr $102: 152-155$

112. Welch RW, Bentch HL, Harris StC (1978) Reduction of aspirininduced gastrointestinal bleeding with cimetidine. Gastroenterology 74:459-463

113. Wolf S, Wolff HG (1957) Human Gastric Function, New York, Oxford, 1947 (quoted by Weisz JD) Psychosomatic Med 19:62-73

Received December 19, 1979

Accepted January 16,1980

Prof. Dr. W. Lorenz

Abt. f. Exp. Chirurgie

Zentrum f. Chirurgie

der Universität

Robert-Koch-Str. 8

D-3550 Marburg

Federal Republic of Germany 